\title{
Fertigation Effect on Carnation under Polyhouse in North Bihar Agro-Climatic Conditions
}

\author{
S.K. Nirala*, R. Suresh and Sunil Kumar \\ Precision Farming Development Centre, Department of Soil and Water Engineering, College \\ of Agriculture Engineering, Dr.R.P.C.A.U., Pusa (Samastipur) Bihar -848125, India \\ *Corresponding author
}

\section{Keywords \\ Polyhouse, Carnation, Water requirement, Fertigation, B/C ratio}

Article Info

Accepted:

20 July 2018

Available Online:

10 August 2018

\section{A B S T R A C T}

A study on "Fertigation Effect in Carnation under Polyhouse in North Bihar Agro-climatic conditions" was carried out under twelve (12) treatments, i.e., 3 main treatments on variety, namely; $\mathrm{V}_{1}$ : Loris; $\mathrm{V}_{2}$ : Pingu and $\mathrm{V}_{3}$ : Gioele, and 4 sub- treatments on fertigation, i.e., $\mathrm{F}_{1}: 80 \%$ fertigation of RDF of NPK; $\mathrm{F}_{2}: 100 \%$ fertigation of NPK; $\mathrm{F}_{3}: 120 \%$ fertigation of NPK and $\mathrm{F}_{4}: 100 \%$ application of RDF (control) adopting split plot design. The average daily month wise water requirement per plant of Carnation was computed minimum $0.12 \mathrm{~cm}$ in January and maximum $0.56 \mathrm{~cm}$ April. The total water requirement during crop period was found to be $66.56 \mathrm{~cm}$. Among different varietal treatments, the treatment $\mathrm{V}_{2}$ (Pingu) recorded maximum number of branches (9.80); minimum days for bud initiation (89.83 days) and flowering(164.83 days); maximum flower diameter $(7.83 \mathrm{~cm})$ and stalk length $(60.22 \mathrm{~cm})$ and girth $(4.43 \mathrm{~mm})$ as well as maximum number of flowers per $\mathrm{m}^{2}$ area 353 .The fertigation treatment $\mathrm{F}_{3}$ (120\% fertigation of RDF of NPK) was found very effective, might be due to application of higher doses, resulted maximum plant heights $87.18 \mathrm{~cm}$ at 210 DAT. Also, the number of branches (11.59); minimum time for bud formation (87.89 days), minimum days to flowering (165.11 days), maximum stalk length $(57.83 \mathrm{~cm})$ and girth $(4.91 \mathrm{~mm})$ as well as maximum number of flower per $\mathrm{m}^{2}$ area (353.22). The $\mathrm{b} / \mathrm{c}$ ratio was also found highest in treatment $\mathrm{F}_{3}$, i.e. $2.60,2.56$ and 2.59 whereas lowest $0.81,0.96$ and 0.85 found in control treatment $\left(F_{4}\right)$ for Loris, Pingu and Gioele respectively.

\section{Introduction}

India is the second largest producer of flowers after China (http://business.gov.in). During the tenth plan an additional 10000 ha have been brought under the traditional flower sector by the end of 2004-05 to register an overall area of 1.16 lakh ha. Indian exports of floriculture products is valued at Rs. 100 crores. There has been an impressive growth in the export of cut flowers from Rs. 1 crore in 1987-88 to Rs 100 crores in 1998. The floriculture industry is growing at the rate of 7-10 percent per annum. During 2004, the turnover was Rs.30 billion 
with a contribution of Rs. 5 billion from Delhi alone followed by Rs 4.5 billion from Bangalore. The industry is characterized by sale of most loose flowers and the export surplus from the cut-flower (rose, carnation, gerbera, orchids and anthuriums) industries. With the growing competitiveness, floriculture units in India have been facing several constraints, so there is a need to develop optimum conditions for growing cut flowers.

Since last decade, the term "fertigation" coined with two words i.e. fertilizer and irrigation is introduced with micro irrigation. Fertigation is well recognized as the most effective and convenient means of maintaining optimum fertility level and water supply according to the specific requirements of the crop and soil, resulting into higher yields and better quality. The fertilizers applied through the micro irrigation (MI) system is available in the root zone at field capacity(F.C) state and gets easily absorbed by the plant. Fertigation caused a great effect on fertilizer saving. Research has revealed that more than 40 percent saving of fertilizer can be achieved by fertigation through drip system with a substantial increase in yield. Water is also saved ranging from 39 to 62 percent along with an increase in production. The irrigation efficiency of micro irrigation system has been reported to the tune of 90 to 95 percent. In contrast, the irrigation efficiency of the traditional method is hardly 60 to $70 \%$ because of greater loss due to leaching and surface runoff.

Amongst different prevailing flower varieties under cultivation in north Bihar agro climatic condition, the carnation is quite new. Its feasibility evaluation under north Bihar agroclimatic condition has been filt essential considering its increasing demand in the state. The use of a greenhouse along with the MI system for irrigation and fertigation for carnation cultivation will certainly provide a conducive result on yield, quality and longivity in the carnation harvesting span. Considering aforesaid points in view, an attempt has been made to explore the feasibility of carnation cultivation inside the polyhouse under a specific topic entitled "Fertigation effect on carnation under polyhouse in North Bihar Agro-climatic conditions ". The study is the part of the research scheme entitled "Precision Farming Development Centre (PFDC)" financed by the National Committee on Plasticulture Applications in Agriculture and Horticulture (NCPAH), Ministry of Agriculture, Govt. of India. The specific objectives of the research work to evaluate the water requirement of the carnation crop under poly house condition, fertigation effects and evaluate the costeconomics of carnation cultivation.

Aydnsakir et al., (2009) conducted a study to determine the effects of different irrigation levels on flowering and flower quality of carnation in greenhouse using drip irrigation. Two irrigation intervals (10 and $20 \mathrm{~mm}$ pan evaporation) and four pan coefficient levels (0.60, 0.90, 1.20 and 1.50 Epan) were applied. Result revealed that high frequency irrigations using high pan coefficients increased flower stem length, flower stem diameter, stem weight, flower diameter, vase life and yield as compared to the low frequency irrigation with lower pan coefficients. Yamanaka et al., (2011b) evaluated the effects of flower bearing types and pinching methods on the characteristics of water consumption in winter-spring harvest cropping type carnation under fertigation treatment. They developed regression equation amongst amount of water consumption integrated solar radiation and the leaf number as $\mathrm{y}=0.00697 \mathrm{X}_{1}+0.00930 \mathrm{X}_{2-}$ 1.36616, regardless of cultivar or pinching methods. Krishna et al., (1999) conducted research trial on carnation cultivars Kristina, Aleda, Master and Vienna grown from the cuttings and fertigated at the level of 80, 100 
and $120 \%$ of the recommended fertilizer dose. They reported that the fertigation levels had no significant effect on plant height up to 90 days after planting (DAP), bud length, bud diameter, flower diameter, stem length, number of flowers, flower yield etc. Interactions between fertigation and cultivars were formed for plant height after 105 DAP.

Yamanaka et al., (2011a) evaluated the effect of three planting patterns i.e. two-row-planting high density (25 plants. $\mathrm{m}^{2}$ ), two-row-planting low density (12.5 plants. $\left.\mathrm{m}^{2}\right)$, and four-rowplanting (25 plants. $\mathrm{m}^{2}$ ) on carnation (Dianthus caryophyllus L.) cv. 'Barbara' and 'Cherry Tessino' with fertigation. There was no difference in cut flower quality between tworow-planting high density and four-rowplanting in both the cultivars. Cut flower weight and stem diameter of two-row-planting with low density was superior as compared to two-row-planting high density or four-rowplanting. In nut shel, the result indicates that two-row-planting high density is suitable for carnation.

Bhautkar (1994) reported variation in number of branches ranging from 10 in varieties Lena, Scania and Arthur Sim to 18 in Eveline under greenhouse condition. Patil (2001) noticed that the variety Madame Collette recorded maximum number of branches (4.52), followed by Desio (4.35) and Alma (4.22), while Leon recorded minimum number of branches (2.85) at 180 DAP. Singh and Singh (2005) reported that, the maximum number of branches (9.5) were observed in the treatment of double pinching and application of 500 ppm nitrogen, followed by (9.1) in double pinching and $200 \mathrm{ppm}$ nitrogen application. Bhautkar (1994) conducted study to evaluate the performance of 10 varieties under greenhouse and reported that cultivar Barbara was the earliest to initiate. However, cultivar Eveline took 119 days for bud initiation. In another study reported that the cultivar Sterile
DOP (spray) was found earliest (122.06 days), whereas cultivar Pink (Standard) late (166.77 days) for bud initiation (Mahesh, 1996). Krishnappa et al., (2000) reported that the varieties differed significantly for number of days taken for bud opening under low cost greenhouse. The cultivar Master took maximum number of days (63.8) for bud opening, while Vienna took minimum number of days (60.6) for bud opening. Shahkar et al., (2004) studies various verities regarding bud opening under greenhouse. They reported that the cultivar Salsa took minimum number of days (20.60 days) for flower opening, while cultivar Super green noticed maximum number of days for flower opening. Singh et al., (2006) noted maximum flower diameter $(6.61 \mathrm{~cm})$ in case of availability of 4 hour additional light, and minimum $(5.76 \mathrm{~cm})$ under natural day length.

\section{Materials and Methods}

The experiment was carried out at the Hi-Tech Horticulture centre, Rajendra Agricultural University Pusa Samastipur Bihar under "Precision Farming Development Centre (PFDC)" financed by the National Committee on Plasticulture Application in Agriculture and Horticulture (NCPAH), Ministry of Agriculture and farmers welfare, GoI, New Delhi, running in the department of Soil and Water Conservation Engineering, College of Agricultural Engineering, R, A. U., Pusa, Samastipur. It is situated at $25^{\circ} 59^{\prime} \mathrm{N}$ latitude and $85^{\circ} 48 \mathrm{E}$ longitude. Altitude of the site is $52.92 \mathrm{~m}$ above mean sea level. Experimental site is under humid sub-tropical climate, greatly influenced by the south-west monsoon. The main characteristic of the climate is hotdry summer followed by cold winters. Average annual rainfall is $1270 \mathrm{~mm}$, out of which about $1026 \mathrm{~mm}$ is received during the monsoon season from June to October. Soil type is sandy clay loam with average available moisture content $12.01 \%$ 
The experiment consists of twelve treatments viz., four fertigation levels $80 \%, 100 \%, 120 \%$ and $100 \%$ (traditional) of recommended fertilizer dose (140:80:120 g NPK/m $\left.{ }^{2}\right)$ and three standard varieties (Loris, Pingu, Gioele) under split plot design (SPD).

\section{Treatments details}

$\begin{array}{ll}\text { A. } & \text { Main plot: } \\ \mathrm{V}_{1} & \text { Lo3 }) \text { Varieties } \\ \mathrm{V}_{2} & \text { Loris } \\ \mathrm{V}_{3} & \text { Pingu } \\ & \text { Gioele }\end{array}$

B. Sub plot: (04) Fertigation level

$\mathrm{F}_{1} \quad 80 \%$ Fertigation of RDF of NPK

$\mathrm{F}_{2} \quad 100 \%$ Fertigation of RDF of NPK

$\mathrm{F}_{3} \quad 120 \%$ Fertigation of RDF of NPK

$\mathrm{F}_{4} \quad 100 \%$ Application of RDF manually

\section{Layout plan}

The experiment was laid out considering split plot design (SPD) with varieties in main plots and fertigation levels in sub-plots for three replications. The details of layout plan of experimental design showing the allocation of different treatments (main and sub-main)

\section{Details of field layout \\ Crop \\ Varieties \\ Spacing:- \\ row to row \\ plant to plant \\ Design \\ Main plot treatments \\ Sub-plot treatments \\ Replications \\ Total number of plots \\ Total plot area \\ Net plot size

\author{
Carnation (Diathus caryaphylles L.) \\ $\mathrm{V}_{1}, \mathrm{~V}_{2}$ and $\mathrm{V}_{3}$ \\ $20 \mathrm{~cm}$ \\ $15 \mathrm{~cm}$ \\ Split plot \\ $3\left(\mathrm{~V}_{1}, \mathrm{~V}_{2}\right.$ and $\left.\mathrm{V}_{3}\right)$ \\ $4\left(\mathrm{~F}_{1}, \mathrm{~F}_{2}, \mathrm{~F}_{3}\right.$ and $\left.\mathrm{F}_{4}\right)$ \\ 3 \\ 36 \\ $20 \mathrm{~m} \times 10 \mathrm{~m}$ \\ $17 \mathrm{~m} \times 8 \mathrm{~m}$ (Deducing $20 \mathrm{~cm}$ as path width \\ between treatment/replications)
}

\section{Crop water requirement}

The daily water requirement to be applied for irrigation to carnation inside green house was calculated using following formula (Anonymous 1997)

$\mathrm{ET}_{\mathrm{c}}=\mathrm{E}_{\mathrm{P}} \times \mathrm{K}_{\mathrm{P}} \times \mathrm{K}_{\mathrm{C}} \times \mathrm{W}_{\mathrm{P}}$

Where,

$\mathrm{ET}_{\mathrm{c}}=$ Evapotranspiration rate in $\mathrm{mm} / \mathrm{day}$

$\mathrm{E}_{\mathrm{P}} \quad=$ pan evaporation in $\mathrm{mm} /$ day
$\mathrm{K}_{\mathrm{P}} \quad=$ Pan- Coefficient

$\mathrm{K}_{\mathrm{C}} \quad=$ Crop factor/crop coefficient

$\mathrm{W}_{\mathrm{P}} \quad=$ Wetted area factor

The data on daily pan evaporation was collected by installing pan evaporimeter inside green house, planted with carnation, for the period October 2012 to June 2013. To compute the water requirement of carnation under greenhouse, the values of other requisite parameters are taken $\mathrm{K}_{\mathrm{p}}$ varies from 0.6 to 0.8 
but for USWB Class-A pan evaporimeter it is recommended to be 0.8 . The value of $\mathrm{K}_{\mathrm{c}}$ depends on the of crop, growing stage, metrological condition mainly It's value for carnation crop for different growing stages is consider as per follows (FAO 56).

Initial stage $=0.60$ Development stage $=0.70$ to 0.90 , Middle stage $=1.0$ to 1.20

Late stage $=1.10$, the value of wetted factor for carnation $\left(\mathrm{W}_{\mathrm{p}}\right)$ was taken 0.9 .

\section{Fertilizer dose and application}

The RDF used in practice at $\mathrm{Hi}$ tech Horticulture RAU Pusa, is to the tune of 140:80:120 g/m ${ }^{2}$ NPK respectively, in which $50 \%$ of RDF was applied as basal dose, and rest $50 \%$ was applied through fertigation.

Also, the quantity of fertilizers/FYM used to apply nutrients (N,P \& K) as per recommended dose under different treatments $\left(\mathrm{F}_{1}, \mathrm{~F}_{2}, \mathrm{~F}_{3} \& \mathrm{~F}_{4}\right)$ were workout.

\section{Irrigation and fertigation schedule}

Carnation is very sensitive to moisture stress. A little moisture affects the plant growth and development of branches in the plant, significantly. Emergence of branches results into yield of flowers or yield. Considering this in the view of irrigation was scheduled at daily basis, to feed daily water requirement.

Application of fertilizer (NPK) as per required dose under different treatments $\left(\mathrm{F}_{1}, \mathrm{~F}_{2}, \mathrm{~F}_{3}\right.$ \& $\mathrm{F}_{4}$ ) was carried out along with irrigation water, through fertigation unit equipped in drip systems.

In present study, the venture type fertigation system along with fertilizer tank was used for fertigation. The requisite amount of fertilizer under different treatments was dissolve in water and formed a kind of fertilizer solution, was kept in to fertilizer tank. On drip system operation, the fertilizer solution kept in fertilizer tank gets automatically sucked by the venture system, and mixed in water flow.

\section{Vegetative growth parameters}

The plant height, total number of lateral shoots produced per plant after pinching of the tagged plants was measured from the base to the tip of plant at monthly interval in treatment wise. Flowering parameters such as number of days of bud opening from transplanting, flower's stalk length, stalk girth, diameter, quality parameter, number of flowers per plant and number of flowers per square meter was measurement recorded.

\section{Evaluation of cost- economics of carnation crop}

The cost-economics of carnation crop was evaluated for different treatments separately in terms of benefit-cost ratio $(\mathrm{b} / \mathrm{c})$. Computation was carried out based on the following input costs.

\section{Cost of cultivation}

The total incurred cost, i.e. the cost of cultivation under drip irrigation system for irrigating and fertigation crop was determined as the sum of 1 . Cost of greenhouse, 2. Operating cost of tube well and pump 3 . Operating cost of drip system; and 4. Cost of field experiment.

Benefit- cost ratio: The b/c ratio was computed as the ratio of benefit realized to the costs invested under cultivation, given as below:

$b / c=\frac{\text { Benefit } \quad \text { realized from cultivatio } \mathrm{n}}{\text { Cost of cultivatio } \mathrm{n}} \quad . .2 .2$ 


\section{Results and Discussion}

\section{Crop water requirement}

The water requirement varies from maximum $16.67 \mathrm{~cm}$ in April to minimum $3.66 \mathrm{~cm}$ in the month of December. However, the monthly water requirements for the months October, November, January, February, March and May were computed to the tune of $4.32 \mathrm{~cm}$, $5.05 \mathrm{~cm}, 3.97 \mathrm{~cm}, 5.67 \mathrm{~cm}, 12.75 \mathrm{~cm}$ and $14.65 \mathrm{~cm}$, respectively. Overall, in terms of the total depth of water requirement of carnation during the entire crop period was estimated to be $66.56 \mathrm{~cm}$. In terms of average daily depth of water required per plant, it was $0.15,0.17$, $0.12,0.12,0.20,0.41,0.56$ and $0.47 \mathrm{~cm}$ were computed for the months October to May. Overall, carnation requires very little water for survival.

\section{Response on fertigation applications on plant height}

An appraisal of data regarding plant height as shown in Table 1 reveals that carnation is very sensitive to fertilizer dose, e.g. at 30 DAT the plant maximum height $(28.88 \mathrm{~cm})$ was observed under fertigation treatment $\mathrm{F}_{3}$ (application on 120\% fertigation of NPK of $\mathrm{RDF}$ ) followed by treatment $\mathrm{F}_{2}$ (application on $100 \%$ fertigation of NPK of RDF), $F_{1}$ (application on $80 \%$ fertigation of NPK of $\mathrm{RDF})$, and minimum in treatment $\mathrm{F}_{4}(100 \%$ application of RDF manually) to the tune of $26.08 \mathrm{~cm}, 22.98 \mathrm{~cm}, 20.72 \mathrm{~cm}$, respectively. Similarly, at 60, 90, 120, 150, 180 and 210 DAT, the maximum plant height $28.83 \mathrm{~cm}$, $45.31 \mathrm{~cm}, 62.20 \mathrm{~cm}, 80.33 \mathrm{~cm}, 85.21 \mathrm{~cm}$ and $87.18 \mathrm{~cm}$, respectively in treatment $\mathrm{F}_{3}$, i.e when $120 \%$, RDF was fertigated. The effect of fertigation treatment $F_{1}$ (application of $80 \%$ of $\mathrm{RDF}$ ) was found at par with treatment $\mathrm{F}_{4}$. In treatment $\mathrm{F}_{2}$ (application of $100 \% \mathrm{RDF}$ ), the effect on plant height was noticed in between treatment $\mathrm{F}_{3}$ and $\mathrm{F}_{4}$. The recorded plant heights under $F_{2}$ are to the tune of $26.84 \mathrm{~cm}$, $41.32 \mathrm{~cm}, 59.58 \mathrm{~cm}, 76.80 \mathrm{~cm}, 81.89 \mathrm{~cm}$ and $83.83 \mathrm{~cm}$ respectively at $60,90,120,150,180$ and 210DAT. Statistically, the CV values of plant heights vary from minimum 3.72 at 150DAT and maximum 6.07 at 60DAT, whereas $\mathrm{CD}$ was minimum 1.34 at 30DAT and maximum 3.00 at 180 and 210DAT. Overall, the interaction between varieties and fertigation treatments was found nonsignificant.

\section{Yield number of flower per square meter}

The data on number of flowers per square meter as affected by varieties and fertigation levels are presented in Table 2.

\section{Effect of varieties}

With regard to the effect of varieties on number of flower per square meter area, there is variety wise variation. Amongst all the variety $\mathrm{V}_{2}$ (Pingu) appeared to produce highest number of flowers per square meter area, i.e 281.00 , followed by variety $\mathrm{V}_{3}$ (Gioele) 273.75 and $V_{1}$ (Loris) 269.25 flowers per square meter area. Statistically, it was non significant at 5\% $\mathrm{CD}$, the $\mathrm{CV}$ value is found 3.74 .

\section{Effect of fertigation}

Perusal of data revealed that the fertigation levels have significant effect on yielding the number of flowers per square meter area. Amongst different fertigation levels, the maximum number of flowers per square meter (352.22) was recorded in treatment F3 (application on $120 \%$ fertigation of NPK of RDF) which is superior over treatment $\mathrm{F}_{2}$ (application on $100 \%$ fertigation of NPK of RDF), 301.56 flowers per square meter area, $\mathrm{F}_{1}$ (application on $80 \%$ fertigation of NPK of RDF) 274.56 flowers $/ \mathrm{m}^{2}$ and $\mathrm{F}_{4}(100 \%$ application of RDF manually) 170.33 flowers $/ \mathrm{m}^{2}$. The treatment $\mathrm{F}_{1}$ was statistically 
at par with control treatment $\mathrm{F}_{4}$. Overall, in comparison to control treatment the percentage increase in number of flowers per square meter area was estimated to be $61.20 \%$ in $\mathrm{F}_{1} ; 77.04 \%$ in $\mathrm{F}_{2}$ and $106.78 \%$ in treatment $\mathrm{F}_{3}$. The $\mathrm{CD}$ and $\mathrm{CV}$ values are found 10.17 and 3.74 , respectively.

\section{Cost of cultivation}

In order to evaluate the feasibility of carnation cultivation under greenhouse with fan and pad cooling system, the response of different varieties of carnation were used under research study. The benefit/cost ratio was analyzed for each variety. On comparison, it was found that there is little variation in the $\mathrm{b} / \mathrm{c}$ ratio amongst different varieties, but there was a significant difference in respect of fertigation doses. This fact reveals that carnation is very sensitive to nutrient. The fertigation treatment $\mathrm{F}_{3}$ in which $120 \%$ RDF was applied through fertigation, resulted highest b/c ratio to the tune of 2.60, 2.59 and 2.56 in varities $\mathrm{V}_{1}$ (Loris), $\mathrm{V}_{3}$ (Gioele) and $\mathrm{V}_{2}$
(Pingu) respectively. On the other hand, the fertigation treatment $\mathrm{F}_{4} \quad(100 \% \quad \mathrm{RDF}$ application through, manually) showed a minimum $\mathrm{b} / \mathrm{c}$ ratio in all the varieties, 0.96, $0.85,0.81$ in $\mathrm{V}_{2}, \mathrm{~V}_{3}$ and $\mathrm{V}_{1}$, respectively. The treatment $\mathrm{F}_{2}(100 \%$ RDF through fertigation) was next to $\mathrm{F}_{3}$ for resulting b/c ratio, which was $2.27,2.11$ and 2.00 in varieties $V_{2}, V_{3}$ and $\mathrm{V}_{1}$, respectively, followed by treatment $\mathrm{F}_{1}$, $1.89,1.87$ and 1.79 in varieties $V_{2}, V_{3}$ and $V_{1}$, respectively. Overall, amongst different varieties the variety $V_{2}$, which is Pingu, relatively good, followed by $\mathrm{V}_{3}$ (Gioele)

In conclusion, the fertigation which combines irrigation with fertilizers is the most effective and convenient means of maintaining optimum fertility level and water supply according to the specific requirement of crops with drip system. Drip irrigation is the precise water application method which saves water by reducing the size of wet soil surface and thus decreasing the amount of direct evaporation and excess water percolation from the root zone.

Table.1 Effect of plant height $(\mathrm{cm})$ on carnation under different varieties and different levels of Fertigation

\begin{tabular}{|l|l|l|l|l|l|l|l|}
\hline & 30 DAT & 60 DAT & 90 DAT & 120 DAT & 150 DAT & 180 DAT & 210 DAT \\
\hline $\mathbf{V}_{\mathbf{1}}$ & 28.12 & 29.92 & 44.55 & 62.92 & 82.30 & 87.64 & 90.10 \\
\hline $\mathbf{V}_{\mathbf{2}}$ & 23.65 & 23.36 & 39.94 & 54.40 & 70.62 & 74.53 & 77.48 \\
\hline $\mathbf{V}_{\mathbf{3}}$ & 22.23 & 22.45 & 37.11 & 56.11 & 74.50 & 78.58 & 81.63 \\
\hline $\mathbf{S . E m}( \pm)$ & 0.49 & 0.64 & 0.81 & 1.02 & 0.80 & 1.11 & 0.81 \\
\hline $\mathbf{C D}$ & 1.93 & 2.51 & 3.19 & 4.01 & 3.14 & 4.35 & 3.16 \\
\hline $\mathbf{C V}$ & 6.92 & 8.79 & 6.92 & 6.12 & 3.66 & 4.78 & 3.36 \\
\hline $\mathbf{F}_{\mathbf{1}}$ & 22.98 & 23.32 & 37.64 & 55.24 & 74.98 & 79.04 & 82.74 \\
\hline $\mathbf{F}_{\mathbf{2}}$ & 26.08 & 26.84 & 41.32 & 59.58 & 76.80 & 81.89 & 83.83 \\
\hline $\mathbf{F}_{\mathbf{3}}$ & 28.88 & 29.97 & 45.31 & 62.20 & 80.33 & 85.21 & 87.18 \\
\hline $\mathbf{F}_{\mathbf{4}}$ & 20.72 & 21.97 & 37.85 & 54.21 & 71.11 & 74.86 & 78.83 \\
\hline $\mathbf{S . E m}( \pm)$ & 0.45 & 0.51 & 0.66 & 0.83 & 0.94 & 1.00 & 1.01 \\
\hline $\mathbf{C D}$ & 1.34 & 1.52 & 1.95 & 2.46 & 2.80 & 3.00 & 2.99 \\
\hline $\mathbf{C V}$ & 5.49 & 6.07 & 4.83 & 4.29 & 3.72 & 3.76 & 3.64 \\
\hline $\mathbf{V x F}$ & $\mathrm{NS}$ & NS & NS & NS & NS & NS & NS \\
\hline
\end{tabular}

$\left(\mathrm{V}_{1}=\right.$ Loris $; \mathrm{V}_{2}=$ Pingu and $\mathrm{V}_{3}=$ Gioele $)$ 
Table.4 Average daily water requirement of carnation plant during different months

\begin{tabular}{|c|c|c|c|c|c|c|c|c|}
\hline \multirow[t]{2}{*}{ Month } & \multirow{2}{*}{$\begin{array}{l}\text { Avg. Daily } \\
\text { evaporation } \\
\text { (Ep) } \\
(\mathbf{m m} / \text { day })\end{array}$} & \multirow{2}{*}{$\begin{array}{l}\text { Pan } \\
\text { coefficient } \\
\left(\mathbf{K}_{\mathbf{p}}\right)\end{array}$} & \multirow{2}{*}{$\begin{array}{l}\text { Crop } \\
\text { coefficient } \\
\left(\mathbf{K}_{\mathbf{c}}\right)\end{array}$} & \multirow{2}{*}{$\begin{array}{l}\text { Average } \\
\text { wetted } \\
\text { Area } \\
\text { factor }\left(W_{P}\right)\end{array}$} & \multirow{2}{*}{$\begin{array}{l}\text { Area } \\
\left(\mathbf{m}^{2}\right)\end{array}$} & \multicolumn{2}{|c|}{ Crop water requirement } & \multirow{2}{*}{$\begin{array}{l}\text { Monthly } \\
\text { depth of } \\
\text { water } \\
\text { applied } \\
\text { (mm) }\end{array}$} \\
\hline & & & & & & $\begin{array}{l}\text { Liters } \\
\text { /day } \\
\text { /plant }\end{array}$ & $\begin{array}{l}\text { Daily (Av.) water } \\
\text { requirement } \\
(\mathbf{m m})\end{array}$ & \\
\hline $\begin{array}{l}\text { Oct, } \\
2012\end{array}$ & 3.57 & 0.8 & 0.6 & 0.9 & 0.03 & 0.05 & 1.5 & 43.2 \\
\hline $\begin{array}{l}\text { Nov, } \\
2012\end{array}$ & 3.37 & 0.8 & 0.7 & 0.9 & 0.03 & 0.05 & 1.7 & 50.5 \\
\hline $\begin{array}{l}\text { Dec, } \\
2012\end{array}$ & 2.05 & 0.8 & 0.8 & 0.9 & 0.03 & 0.04 & 1.2 & 36.6 \\
\hline $\begin{array}{l}\text { Jan, } \\
2013\end{array}$ & 1.89 & 0.8 & 0.9 & 0.9 & 0.03 & 0.04 & 1.2 & 39.7 \\
\hline $\begin{array}{l}\text { Feb, } \\
2013\end{array}$ & 2.81 & 0.8 & 1.0 & 0.9 & 0.03 & 0.06 & 2.0 & 56.7 \\
\hline $\begin{array}{l}\text { March, } \\
2013\end{array}$ & 4.76 & 0.8 & 1.2 & 0.9 & 0.03 & 0.12 & 4.1 & 127.5 \\
\hline $\begin{array}{l}\text { April, } \\
2013\end{array}$ & 6.43 & 0.8 & 1.2 & 0.9 & 0.03 & 0.17 & 5.6 & 166.7 \\
\hline $\begin{array}{l}\text { May, } \\
2013\end{array}$ & 5.96 & 0.8 & 1.1 & 0.9 & 0.03 & 0.14 & 4.7 & 146.5 \\
\hline & & & & & & & Total & 665.6 \\
\hline
\end{tabular}

Table.2 Effects of varieties and fertigation levels on number of flowers per square meter area

\begin{tabular}{|c|c|c|c|c|c|}
\hline \multirow{2}{*}{$\begin{array}{l}\text { Sub- } \\
\text { Treatment(Fertigation) }\end{array}$} & \multicolumn{5}{|c|}{ Main treatment(Varieties) } \\
\hline & $\mathrm{V}_{1}$ & $\mathrm{~V}_{2}$ & $\mathrm{~V}_{3}$ & Mean & $\begin{array}{l}\text { Percentage } \\
\text { variation over } \\
\text { control }\end{array}$ \\
\hline $\mathbf{F}_{1}$ & 267.00 & 276.67 & 280.00 & 274.56 & 61.20 \\
\hline $\mathbf{F}_{2}$ & 290.33 & 316.67 & 297.67 & 301.56 & 77.04 \\
\hline $\mathbf{F}_{3}$ & 353.33 & 350.00 & 353.00 & 352.22 & 106.78 \\
\hline $\mathbf{F}_{4}$ & 166.33 & 180.67 & 164.00 & 170.33 & - \\
\hline Mean & 269.25 & 281.00 & 273.75 & & - \\
\hline Treatments & S.Em $( \pm)$ & $\mathrm{CD}(5 \%)$ & & & $\mathrm{CV}$ \\
\hline Main treatment & 4.83 & NS & & 6.08 & \\
\hline Sub treatment & 3.43 & 10.17 & & 3.74 & \\
\hline
\end{tabular}

$$
\left(\mathrm{V}_{1}=\text { Loris; } \mathrm{V} 2 \text { = Pingu and } \mathrm{V}_{3}=\text { Gioele }\right)
$$


Table.3 Performance of carnation under poly house

\begin{tabular}{|l|l|l|l|l|l|l|}
\hline Treatments & $\begin{array}{l}\text { Avg. } \\
\text { number of } \\
\text { braches }\end{array}$ & $\begin{array}{l}\text { Avg. length } \\
\text { of flower } \\
\text { stake }(\mathrm{cm})\end{array}$ & $\begin{array}{l}\text { Avg. } \\
\text { flower } \\
\text { bud length } \\
\text { (cm) }\end{array}$ & $\begin{array}{l}\text { Avg. } \\
\text { flower } \\
\text { diameter } \\
\text { (cm) }\end{array}$ & $\begin{array}{l}\text { Numbers } \\
\text { of flowers/ } \\
\text { Sqm }\end{array}$ & $\begin{array}{l}\text { Benefit Cost } \\
\text { ratio }\end{array}$ \\
\hline V1F1 & 9.33 & 59.40 & 5.17 & 6.40 & 267.00 & 1.79 \\
\hline V1F2 & 10.47 & 62.83 & 5.53 & 6.58 & 290.33 & 2.00 \\
\hline V1F3 & 11.60 & 64.13 & 5.33 & 6.39 & 353.33 & 2.60 \\
\hline V1F4 & 6.53 & 54.50 & 5.33 & 6.31 & 166.33 & 0.81 \\
\hline V2F1 & 9.93 & 46.50 & 4.53 & 7.34 & 276.67 & 1.89 \\
\hline V2F2 & 10.87 & 52.73 & 4.53 & 7.35 & 316.67 & 2.27 \\
\hline V2F3 & 11.97 & 53.33 & 4.27 & 7.83 & 350.00 & 2.56 \\
\hline V2F4 & 6.43 & 46.43 & 4.27 & 4.37 & 180.67 & 0.96 \\
\hline V3F1 & 9.47 & 50.93 & 4.23 & 6.38 & 280.00 & 1.87 \\
\hline V3F2 & 10.20 & 51.97 & 4.10 & 6.33 & 297.67 & 2.11 \\
\hline V3F3 & 11.20 & 56.83 & 4.17 & 6.40 & 353.00 & 2.59 \\
\hline V3F4 & 6.23 & 46.27 & 4.00 & 6.40 & 164.00 & 0.85 \\
\hline
\end{tabular}

On the basis of data recorded and analysed under different treatments the pertinent findings with respect to different objectives under taken, are concluded below: The water requirement varies from maximum $166.7 \mathrm{~mm}$ in April to minimum $36.6 \mathrm{~mm}$ in the month of December (Table 4). The total depth of water requirement of carnation during the entire crop period was estimated to be $665.6 \mathrm{~mm}$ (Table 3).

Amongst different treatments on fertigation, selected under study the treatment $\mathrm{F}_{3}(120 \%$ fertigation with $\mathrm{RDF}$ ) proved to be very effective. The maximum plant height was recorded in variety $\mathrm{V}_{1}$ (Loris) at different growth stages, i.e., at $30,60,90,120,150,180$ and 210 DAT which was $28.12 \mathrm{~cm}, 29.92 \mathrm{~cm}$, $44.55 \mathrm{~cm}, 62.92 \mathrm{~cm}, 82.30 \mathrm{~cm}, 87.64 \mathrm{~cm}$ and $90.10 \mathrm{~cm}$, respectively. The fertigation treatment $\mathrm{F}_{3}$ recorded higher plant height at $30,60,90,120,150,180$ and 210 DAT i.e., $28.88 \mathrm{~cm}, 28.83 \mathrm{~cm}, \quad 45.31 \mathrm{~cm}, \quad 62.20 \mathrm{~cm}$, $80.33 \mathrm{~cm}, 85.21 \mathrm{~cm}$ and $87.18 \mathrm{~cm}$, respectively.

The benefit-cost ratio, justifies the feasibility of carnation cultivation under polyhouse in north-Bihar agro-climatic condition which was found to be highest in fertigation treatment $F_{3}$, i.e. $2.60,2.56$ and 2.59 for the varieties $\mathrm{V}_{1}, \mathrm{~V}_{2}$ and $\mathrm{V}_{3}$, respectively. The lowest $\mathrm{b} / \mathrm{c}$ ratio $0.81,0.96$ and 0.85 , was recorded in control treatment $\left(\mathrm{F}_{4}\right)$, for all three varieties i.e. Loris, Pingu and Gioele, respectively.

\section{Acknowledgement}

The authors gratefully acknowledge to the National Committee on Plasticulture Applications in Agriculture and Horticulture (NCPAH), Ministry of Agriculture \& farmers welfare, Govt. of India which provide the fund for conducting the experiment under PFDC.

\section{References}

Anonymous (1997).Training manual on use of plastic in agriculture, $\mathrm{NCPH}$, Ministry of agriculture, New Delhi Aydnsakir, K., Ozcelik, A., Buyuktas, D., 
Tuzel, I.H. (2009). Quality characteristics of drip irrigated carnation (Dianthus caryophyllus L. cv. "Eilat") under protected conditions. Acta-Horticulturae 807 (1): 307-312.

Bhautkar, M. Y., (1994). Carnation cultivation in greenhouse under Mahabaleshwar condition. J. Maharashtra Agric. Uni., 19 (2): 292293.

Mahesh, K., (1996). Variability studies in Carnation (Dianthus caryophyllus L.) M.Sc. Thesis, University of Agricultural Sciences, Bangalore.

Patil, R. T., (2001) Evaluation of standard carnation (Dianthus caryophyllus) cultivars under protected cultivation. $M$. Sc. Thesis, University of Agriculture Sciences, Dharwad.

Sahakar, A. W. and Sable, A. S., (2003). Evaluation of Carnation cultivars under naturally ventilated greenhouse. National Symposium on recent Advances in Indian Floriculture. 1214 November, Kerala Agricultural University

Singh, K. P., and Singh, M. C., (2005). Cultivating Carnation under greenhouse. Indian Horti. 26-27

Singh, R., Singh, K. and Ramesh Kumar,
(2006). Photoperiodic studies on growth and flower production of Carnation cv. Tasman. Haryana $J$. Horti. Sci., 35 (3-4): 260-261.

Krishna, B., Krishnappa, K.S., Reddy, N. S., Anjanappa, M. (1999) Effect of fertigation on growth and yield of carnation cultivars grown under polyhouse.: Mysore Journal of Agricultural Sciences. 33(1): 33-38

Krishnappa, K. S., Shivreddy, N. and Anjanappa, (2000). Effect of floral preservatives on the vase life of Carnation cut flower cultivars. Karnataka Journal of Agricultural Sciences, 13(2): 395-400

Yamanaka, M., Goto, T., Uda, A., Iwai, T., Higashiura, M (2011b) Characteristics of water consumption in winter spring harvest cropping type of carnation. Horticultural Research Japan. 10(1): 33-40

Yamanaka, M., Goto, T., Higashiura, M. (2011a) Effect of planting pattern on cut flower yield, quality of spray carnation grown by fertigation cultivation. Scientific Reports of the Faculty of Agriculture, OkayamaUniversity. 100: 31-37.

\section{How to cite this article:}

Nirala, S.K., R. Suresh and Sunil Kumar. 2018. Fertigation Effect on Carnation under Polyhouse in North Bihar Agro-Climatic Conditions Int.J.Curr.Microbiol.App.Sci. 7(08): 37463755. doi: https://doi.org/10.20546/ijcmas.2018.708.380 